\title{
The voltage-gated $\mathrm{Na}^{+}$channel $\beta 3$ subunit does not mediate trans homophilic cell adhesion or associate with the cell adhesion molecule contactin
}

\author{
Dyke P. McEwen ${ }^{1,2}$, Chunling Chen ${ }^{1}$, Laurence S. Meadows ${ }^{1,3}$, Luis Lopez-Santiago ${ }^{1}$, and \\ Lori L. Isom ${ }^{1,}{ }^{*}$ \\ ${ }^{1}$ Department of Pharmacology, University of Michigan, Ann Arbor, MI 48109-0632
}

\begin{abstract}
Voltage-gated $\mathrm{Na}^{+}$channel (VGSC) $\beta 1$ and $\beta 2$ subunits are multifunctional, serving as both channel modulators and cell adhesion molecules (CAMs). The purpose of this study was to determine whether VGSC $\beta 3$ subunits function as CAMs. The $\beta 3$ extracellular domain is highly homologous to $\beta 1$, suggesting that $\beta 3$ may also be a functional CAM. We investigated the trans homophilic cell adhesive properties of $\beta 3$, its association with the $\beta 1$-interacting CAM contactin, as well as its ability to interact with the cytoskeletal protein ankyrin. Our results demonstrate that, unlike $\beta 1, \beta 3$ does not participate in trans homophilic cell-cell adhesion or associate with contactin. Further, $\beta 3$ does not associate with ankyrin $_{\mathrm{G}}$ in a heterologous system. Previous studies have shown that $\beta 3$ interacts with the CAM neurofascin- 186 but not with VGSC $\beta 1$. Taken together, these findings suggest that, although $\beta 1$ and $\beta 3$ exhibit similar channel modulatory properties in heterologous systems, these subunits differ with regard to their homophilic and heterophilic CAM binding profiles.
\end{abstract}

\author{
Keywords \\ $\mathrm{Na}^{+}$; channel; $\beta$ subunit; cell adhesion molecule
}

\section{Introduction}

Voltage-gated ion channels are multi-functional [20]. In addition to regulating electrical excitability through ion conduction, some voltage-gated ion channels contribute to processes as diverse as intracellular signaling, transcriptional regulation, scaffolding, and cell adhesion without requiring changes in ion flux $[5,6,24]$. For example, VGSC $\beta$ subunits regulate channel transcription, cell surface expression, and subcellular localization, modulate channel currents, and participate in cell-cell adhesion $[4,8,14,17,22,25,31,33]$.

VGSCs isolated from mammalian neurons are heterotrimers, composed of a single $\alpha$ subunit, one non-covalently linked $\beta$ subunit ( $\beta 1$ or $\beta 3$ ), and one disulfide-linked $\beta$ subunit ( $\beta 2$ or $\beta 4$ )

\footnotetext{
(C) 2009 Elsevier Ireland Ltd. All rights reserved.

*To whom correspondence should be addressed: The University of Michigan, Department of Pharmacology, $1150 \mathrm{~W}$. Medical Center Dr., 3422 Med Sci I, SPC 5632, Ann Arbor, MI 48109-5632, Tel.: 734-936-3050, Fax: 734-763-4450, E-mail: lisom@umich.edu. 2Present address: Essen Instruments, Ann Arbor, MI 48108

${ }^{3}$ Present address: Mathematics of Information Technology and Complex Systems, Simon Fraser University, Canada

Publisher's Disclaimer: This is a PDF file of an unedited manuscript that has been accepted for publication. As a service to our customers we are providing this early version of the manuscript. The manuscript will undergo copyediting, typesetting, and review of the resulting proof before it is published in its final citable form. Please note that during the production process errors may be discovered which could affect the content, and all legal disclaimers that apply to the journal pertain.
} 
[7,31]. VGSC $\alpha$ subunit cDNAs express functional channels in heterologous systems. However, for tetrodotoxin-sensitive $\alpha$ subunits, the currents characteristic of these channels expressed in isolation are different from native currents. Co-expression of $\beta$ with $\alpha$ subunits in heterologous systems shifts the voltage-dependence of activation and inactivation, changes the rates of inactivation and recovery from inactivation, and increases channel cell surface expression [5,6,31]. VGSC $\beta$ subunits and the $\beta$ subunits of $\mathrm{Ca}^{2+}$ and $\mathrm{K}^{+}$channels are functionally homologous in terms of channel modulation [2,19]. However, $\mathrm{Ca}^{2+}$ and $\mathrm{K}^{+}$ channel $\beta$ subunits are not structurally homologous to VGSC $\beta$ subunits. Of this group, only the VGSC $\beta$ subunits contain extracellular Ig domains $[18,19]$ and only the VGSC $\beta 1$ and $\beta 2$ subunits have been shown to function as cell adhesion molecules (CAMs) in addition to their roles in channel modulation [5,6]. An important question is whether all of the four known VGSC $\beta$ subunits function as CAMs.

$\beta 1$ and $\beta 2$ function as CAMs: $\beta 1$ and $\beta 2$ interact with the extracellular matrix protein tenascin to influence cell migration [37,41]; $\beta 1$ and $\beta 2$ participate in trans homophilic cell-cell adhesion resulting in cellular aggregation and ankyrin recruitment [26,27]; the $\beta 1$ extracellular Ig domain interacts with the neuronal and glial CAMs contactin, VGSC $\beta 2$, neurofascin-155, neurofascin-186, and NrCAM, but interestingly not with VGSC $\beta 3$ [21,29,30]; $\beta 1$ interactions with contactin and neurofascin-186 result in increased channel cell surface expression [21, $29,30]$; and $\beta 1$ promotes neurite extension as a result of homophilic adhesion $[4,12]$.

The purpose of the present study was to determine whether VGSC $\beta 3$ subunits function as CAMs. The $\beta 3$ extracellular domain is highly homologous to $\beta 1$, suggesting that $\beta 3$ may also be a functional CAM. Consistent with this hypothesis, $\beta 3$ associates with the CAM neurofascin-186 [29,34]. We investigated the trans homophilic cell adhesive properties of $\beta 3$, its association with the $\beta 1$-interacting CAM contactin, as well as its ability to interact with the cytoskeletal protein ankyrin. Our results demonstrate that, unlike $\beta 1, \beta 3$ does not participate in trans homophilic cell-cell adhesion or associate with contactin. Further, $\beta 3$ does not associate with ankyrin ${ }_{\mathrm{G}}$ in a heterologous system. These findings are relevant to recent findings showing that the $S c n 3 b$ null phenotype is subtle and that the null mice are viable [15]. This is in contrast to the severe neurological phenotype of $S c n 1 b$ null mice [8], supporting the hypothesis that physiological role of $\beta 1$ in vivo may include both channel modulation and cell-cell adhesion, while the mechanism of $\beta 3$ function may be less dependent on cell adhesion and more limited to channel modulation.

\section{Materials and Methods}

All experimental procedures are included in the on-line supplemental materials.

\section{Results}

\section{B3-GFP modulates $\mathrm{Na}^{+}$currents expressed in Xenopus oocytes}

To characterize the full scope of $\beta 3$ function, we generated a GFP-tagged $\beta 3$ plasmid, allowing for $\beta 3$ detection using either $\beta 3$ antiserum or a commercial anti-GFP antibody. We coexpressed $\beta 3$-GFP with $\mathrm{Na}_{\mathrm{v}} 1.2$ to determine if the addition of the epitope tag interfered with $\beta 3$-mediated channel modulation. $\beta 3$-GFP cRNA was coinjected with $\mathrm{Na}_{\mathrm{v}} 1.2 \mathrm{cRNA}$ in Xenopus oocytes. As shown in Supplemental Fig. 1 and Supplemental Table 1, $\beta 3$-GFP modulated $\mathrm{Na}^{+}$currents by shifting the half-voltage of inactivation in the hyperpolarizing direction, increasing the rate of inactivation, and increasing the peak current amplitude compared with currents expressed by $\mathrm{Na}_{\mathrm{v}} 1.2$ alone $\left(\mathrm{Na}_{\mathrm{v}} 1.2:-1035 \mathrm{nA}, \mathrm{Na}_{\mathrm{v}} 1.2+\beta 3-\mathrm{GFP}\right.$ : $-2160 \mathrm{nA}$ ), similar to previous reports with untagged $\beta 3[32,35]$. Thus, we used $\beta 3$ and $\beta 3$ GFP interchangeably in all subsequent experiments. 


\section{$\boldsymbol{\beta} 3$ does not participate in trans homophilic cell-cell adhesion}

We used Drosophila $\mathrm{S} 2$ cells previously to demonstrate that VGSC $\beta 1$ and $\beta 2$ subunits function in trans homophilic cell-cell adhesion resulting in ankyrin recruitment [26,27]. S2 cells are ideal for this type of experiment, as they are free-floating in suspension culture, and express no endogenous CAMs. cDNAs encoding putative CAMs to be tested are transfected into S2 cells under an inducible promoter and clonal lines established. Induction of protein expression followed by mechanical shaking allows a detailed analysis of the time course of cellular aggregation. To investigate the trans homophilic cell adhesive properties of $\beta 3$, we expressed $\beta 3$ or $\beta 3-$ GFP in Drosophila S2 cells and established stable, clonal cell lines using soft agar cloning techniques as in [26]. We verified expression of $\beta 3$ or $\beta 3$-GFP in these clonal lines by Western blot analysis with anti- $\beta 3$ or anti-GFP, respectively (Fig. $1 \mathrm{~A}$, anti- $\beta 3$; anti-GFP data not shown). Immunocytochemical analysis of S2- $\beta 3$ and S2- $\beta 3$-GFP cell lines using anti- $\beta 3$ or anti-GFP antibodies showed robust $\beta 3$ expression at the cell surface (Fig. 1B, anti- $\beta 3$; antiGFP data not shown). In spite of this expression, however, we were not able to detect $\beta 3$ mediated cellular aggregation under any condition, including increasing the cell density in the assay, indicating that unlike $\beta 1, \beta 3$ does not mediate trans homophilic cell adhesion in $\mathrm{S} 2$ cells. In parallel experiments and under the same conditions, S2- $\beta 1$ cells exhibited efficient aggregation as described previously [26,27] (data not shown), ensuring that the cell density in the experiment was sufficient to allow aggregation to occur.

\section{$\beta 3$ does not interact with contactin}

We next asked whether $\beta 3$ could interact with the neuronal and glial CAM contactin, as shown for $\beta 1$ [21,29,30]. CHL cells stably expressing contactin were stably cotransfected with $\beta 1$, $\beta 2$, or $\beta 3$-GFP. Triton X-100 solubilized cell lysates were immunoprecipitated with either nonimmune IgG or anti- $\beta$-subunit antibodies. Contactin could be co-immunoprecipitated only from cells expressing $\beta 1$ but not $\beta 2$, in agreement with previous results [30], or $\beta 3$-GFP (Fig. $2 \mathrm{~A})$. To determine whether the presence of a VGSC $\alpha$ subunit altered the ability of $\beta 3$ to associate with contactin, we immunoprecipitated solubilized cells expressing $\mathrm{Na}_{\mathrm{v}} 1.2, \beta 3$, and contactin (Fig. 2B). While $\beta 3$-GFP could be immunoprecipitated with anti- $\beta 3$, anti-contactin was not able to precipitate $\beta 3$, demonstrating that $\beta 3$ and contactin do not associate either in the presence or absence of the ion-conducting pore. While these data demonstrated that $\beta 3$ and contactin do not associate in a heterologous system, they did not indicate whether $\beta 3$ could associate with a contactin-containing complex in brain, where many other channel-associating proteins are present $[5,6]$. To address this question, adult rat brain membrane preparations were solubilized in Triton X-100 and immunoprecipitated with either non-immune IgG, anticontactin, or anti- $\beta 3$, as indicated. The anti- $\beta 3$ immunoprecipitate was positive for contactin (Fig. $2 \mathrm{C}$ ), suggesting that, while $\beta 3$ and contactin likely do not associate directly, a $\beta 3$-contactin containing complex exists in brain. We postulate that the most likely $\beta 3$ binding partner in brain is neurofascin-186, a CAM localized with the VGSC complex at nodes of Ranvier and axon initial segments that associates with both $\beta 1$ and $\beta 3$ subunits as well as ankyrin $[10,11$, $16,34]$.

\section{$\beta 3$ does not interact with ankyrin a}

$\beta 1$ and $\beta 2$ recruit ankyrin to points of cell-cell contact in response to trans homophilic cellcell adhesion [26]. The interaction of $\beta 1$ with ankyrin is dependent on the intracellular tyrosine residue Y181 [27]. Yeast-two-hybrid constructs generating the intracellular domain of $\beta 1$ do not interact with constructs generating ankyrin [3,23], suggesting that extracellular homophilic $\beta 1-\beta 1$ adhesion is required for intracellular signaling. The intracellular domain of $\beta 3$ contains a tyrosine residue at the position corresponding to $\beta 1 \mathrm{Y} 181$ ( $\beta 3 \mathrm{Y} 174)$ ), suggesting that $\beta 3$ may also interact with ankyrin. However, if homophilic cell-cell adhesion is required to signal intracellular ankyrin recruitment by VGSC $\beta$ subunits, then this interaction with $\beta 3$ may not 
take place. To test this, CHL cells were transiently transfected with either $\beta 1$-GFP or $\beta 3$-GFP and ankyrin ${ }_{\mathrm{G}}$-GFP (Fig. 3). Cell homogenates from confluent dishes in which all cells were in contact were solubilized in Triton X-100 and immunoprecipitated either with nonimmune IgG or anti-ankyrin ${ }_{\mathrm{G}}$. Blots were probed with anti-GFP to detect either $\beta 1$-GFP or $\beta 3$-GFP (Fig. 3, arrow). In agreement with previous results, ankyrin $_{\mathrm{G}}$ associated with $\beta 1$ [30]. These results also demonstrated that the presence of the GFP epitope tag on the carboxyl terminus of $\beta 1 \mathrm{did}$ not disrupt its ability to interact with ankyrin ${ }_{\mathrm{G}}$. Under the same conditions, $\beta 3$ did not associate with ankyrin $_{\mathrm{G}}$ despite robust cellular expression levels. Taken together, these results suggest that trans homophilic cell-cell adhesion is required for VGSC $\beta$ subunit-mediated ankyrin recruitment. Further, that $\beta 1$ and $\beta 3$ differ significantly in their signaling properties when expressed in heterologous systems.

\section{Discussion}

In spite of its similarity to $\beta 1, \beta 3$ does not exhibit trans homophilic cell adhesive interactions. The crystal structure of the extracellular domain of $\mathrm{MP}_{\mathrm{o}}[28,36]$ has been used previously to predict structure-function relationships for VGSC $\beta 1$ subunits $[28,36]$. Comparison of the $\beta 3$ Ig domain with the Ig domains of $\beta 1, \beta 2$, and $\mathrm{MP}_{\mathrm{o}}$ reveals a number of important amino acid differences that may explain the absence of $\beta 3$ trans homophilic adhesive activity (Fig. 4).

Four proline residues are present in the $\beta 3 \mathrm{Ig}$ loop domain that are not present in the corresponding positions of the other three molecules: $\beta 3 \mathrm{P} 16$, located in the $\mathrm{A}^{\prime}-\mathrm{B}$ connecting loop of the Ig domain; $\beta 3 \mathrm{P} 63$, located in the C"-D connecting loop of the Ig domain; $\beta 3 \mathrm{P} 109$, located in F-G connecting loop of the Ig domain; and $\beta 3 \mathrm{P} 118$, located within $\beta$ sheet G. P16, $\mathrm{P} 63$, and P109 are positioned in previously described flexible loop segments connecting the $\beta$ sheets $[38,40]$. The presence of prolines in these regions may add rigidity to the flexible loops of the $\beta 3$ Ig domain, limiting its ability to interact with other CAMs. A MP ${ }_{0}$ mutation found in Charcot-Marie-Tooth patients, S49L, is located in the putative homophilic adhesive interface of $\mathrm{MP}_{\mathrm{o}}$ [36,39]. Alignment of this region of $\mathrm{MP}_{\mathrm{o}}$ with the corresponding regions of $\beta 1, \beta 2$, and $\beta 3$ shows a lysine residue at this position in $\beta 1$, a methionine residue in $\beta 2$, and the absence of a corresponding residue in $\beta 3$ (Fig. 4, “-”). If $\mathrm{MP}_{\mathrm{o}} \mathrm{S} 49$ is critical for adhesive interactions, then the lack of a corresponding residue at this position in $\beta 3$ may contribute to its inability to participate in trans homophilic adhesive interactions.

In summary, these data demonstrate that, in spite of its high degree of similarity to $\beta 1, \beta 3$ does not mediate trans homophilic cell adhesion resulting in ankyrin recruitment. While $\beta 1$ and $\beta 3$ both bind to the CAM neurofascin-186 [30,34], they do not bind to each other [29], and of the two, only $\beta 1$ binds to the CAM contactin [21,29,30]. Taken together, these results support the idea that, in spite of similar channel modulatory properties, the structures of the $\beta 1$ and $\beta 3 \mathrm{Ig}$ loop domains are significantly different and their ability to transduce intracellular signals differ as well. This hypothesis is supported by results showing that $S c n l b$, encoding $\beta 1$, but not $S c n 3 b$, encoding $\beta 3$, is expressed in cancer cells where it modulates cell adhesion and migration [9]. In contrast, $S c n 3 b$, unlike $S c n 1 b$, is up-regulated in response to DNA damage and mediates a p53-dependent apoptotic pathway [1]. Thus, these two VGSC $\beta$ subunits may play very different physiological roles in vivo. Finally, the present results in heterologous systems may shed light on recent data showing that that phenotype of $S c n 3 b$ null mice is mild compared to $S c n 1 b$ null mice [15]. It is possible that $S c n 1 b$ compensates for $S c n 3 b$ deletion but not viceversa.

\section{Supplementary Material}

Refer to Web version on PubMed Central for supplementary material. 


\section{References}

1. Adachi K, Toyota M, Sasaki Y, Yamashita T, Ishida S, Ohe-Toyota M, Maruyama R, Hinoda Y, Saito T, Imai K, Kudo R, Tokino T. Identification of SCN3B as a novel p53-inducible proapoptotic gene. Oncogene 2004;23:7791-7798. [PubMed: 15334053]

2. Adelman JP. Proteins that interact with the pore-forming subunits of voltage-gated ion channels. Curr Opin Neurobiol 1995;5:286-295. [PubMed: 7580150]

3. Bouzidi M, Tricaud N, Giraud P, Kordeli E, Caillol G, Deleuze C, Couraud F, Alcaraz G. Interaction of the Nav1.2a subunit of the voltage-dependent sodium channel with nodal ankyrinG. In vitro mapping of the interacting domains and association in synaptosomes. J Biol Chem 2002;277:28996-29004. [PubMed: 12036953]

4. Brackenbury WJ, Davis TH, Chen C, Slat EA, Detrow MJ, Dickendesher TL, Ranscht B, Isom LL. Voltage-gated $\mathrm{Na}+$ channel beta1 subunit-mediated neurite outgrowth requires Fyn kinase and contributes to postnatal CNS development in vivo. J Neurosci 2008;28:3246-3256. [PubMed: 18354028]

5. Brackenbury WJ, Djamgoz MB, Isom LL. An emerging role for voltage-gated Na+ channels in cellular migration: regulation of central nervous system development and potentiation of invasive cancers. Neuroscientist 2008;14:571-583. [PubMed: 18940784]

6. Brackenbury WJ, Isom LL. Voltage-gated Na+ channels: potential for beta subunits as therapeutic targets. Expert Opin Ther Targets 2008;12:1191-1203. [PubMed: 18694383]

7. Catterall WA. Cellular and molecular biology of voltage-gated sodium channels. Physiological Reviews 1992;72:S15-S48. [PubMed: 1332090]

8. Chen C, Westenbroek RE, Xu X, Edwards CA, Sorenson DR, Chen Y, McEwen DP, O'Malley HA, Bharucha V, Meadows LS, Knudsen GA, Vilaythong A, Noebels JL, Saunders TL, Scheuer T, Shrager $\mathrm{P}$, Catterall WA, Isom LL. Mice lacking sodium channel beta1 subunits display defects in neuronal excitability,sodium channel expression, and nodal architecture. J Neurosci 2004;24:4030-4042. [PubMed: 15102918]

9. Chioni AM, Brackenbury WJ, Calhoun JD, Isom LL, Djamgoz MB. A novel adhesion molecule in human breast cancer cells: voltage-gated $\mathrm{Na}+$ channel beta1 subunit. Int J Biochem Cell Biol 2009;41:1216-1227. [PubMed: 19041953]

10. Davis JQ, Bennett V. Ankyrin binding activity shared by the neurofascin/L1/NrCAM family of nervous system cell adhesion molecules. J Biol Chem 1994;269:27163-27166. [PubMed: 7961622]

11. Davis JQ, Lambert S, Bennett V. Molecular composition of the node of ranvier: identification of ankyrin- binding cell adhesion molecules neurofascin (mucin+/third FNIII domain-) and NrCAM at nodal axon segments. J. Cell Biol 1996;135:1355-1367. [PubMed: 8947556]

12. Davis TH, Chen C, Isom LL. Sodium Channel $\beta 1$ Subunits Promote Neurite Outgrowth In Cerebellar Granule Neurons. J. Biol. Chem 2004;279:51424-51432. [PubMed: 15452131]

13. Fein AJ, Meadows LS, Chen C, Slat EA, Isom LL. Cloning and expression of a zebrafish SCN1B ortholog and identification of a species-specific splice variant. BMC Genomics 2007;8:226. [PubMed: 17623064]

14. Fein AJ, Wright MA, Slat EA, Ribera AB, Isom LL. scn1bb, a zebrafish ortholog of SCN1B expressed in excitable and nonexcitable cells, affects motor neuron axon morphology and touch sensitivity. $\mathrm{J}$ Neurosci 2008;28:12510-12522. [PubMed: 19020043]

15. Hakim P, Gurung IS, Pedersen TH, Thresher R, Brice N, Lawrence J, Grace AA, Huang CL. Scn3b knockout mice exhibit abnormal ventricular electrophysiological properties. Prog Biophys Mol Biol 2008;98:251-266. [PubMed: 19351516]

16. Hedstrom KL, Rasband MN. Intrinsic and extrinsic determinants of ion channel localization in neurons. J Neurochem 2006;98:1345-1352. [PubMed: 16787401]

17. Isom LL. The role of sodium channels in cell adhesion. Front Biosci 2002;7:12-23. [PubMed: 11779698]

18. Isom LL, Catterall WA. $\mathrm{Na}^{+}$channel subunits and Ig domains. Nature 1996;383:307-308. [PubMed: 8848042]

19. Isom LL, De Jongh KS, Catterall WA. Auxiliary subunits of voltage-gated ion channels. Neuron 1994;12:1183-1194. [PubMed: 7516685] 
20. Kaczmarek LK. Non-conducting functions of voltage-gated ion channels. Nat Rev Neurosci 2006;7:761-771. [PubMed: 16988652]

21. Kazarinova-Noyes K, Malhotra JD, McEwen DP, Mattei LN, Berglund EO, Ranscht B, Levinson SR, Schachner M, Shrager P, Isom LL, Xiao Z-C. Contactin associates with $\mathrm{Na}^{+}$channels and increases their functional expression. J. Neurosci 2001;21:7517-7525. [PubMed: 11567041]

22. Kim DY, Carey BW, Wang H, Ingano LA, Binshtok AM, Wertz MH, Pettingell WH, He P, Lee VM, Woolf CJ, Kovacs DM. BACE1 regulates voltage-gated sodium channels and neuronal activity. Nat Cell Biol 2007;9:755-764. [PubMed: 17576410]

23. Lemaillet G, Walker B, Lambert S. Identification of a conserved ankyrin-binding motif in the family of sodium channel alpha subunits. J Biol Chem 2003;278:27333-27339. [PubMed: 12716895]

24. Levitan IB. Signaling protein complexes associated with neuronal ion channels. Nat Neurosci 2006;9:305-310. [PubMed: 16498425]

25. Lopez-Santiago LF, Meadows LS, Ernst SJ, Chen C, Malhotra JD, McEwen DP, Speelman A, Noebels JL, Maier SK, Lopatin AN, Isom LL. Sodium channel Scn1b null mice exhibit prolonged QT and RR intervals. J Mol Cell Cardiol 2007;43:636-647. [PubMed: 17884088]

26. Malhotra JD, Kazen-Gillespie K, Hortsch M, Isom LL. Sodium channel $\beta$ subunits mediate homophilic cell adhesion and recruit ankyrin to points of cell-cell contact. J. Biol. Chem 2000;275:11383-11388. [PubMed: 10753953]

27. Malhotra JD, Koopmann MC, Kazen-Gillespie KA, Fettman N, Hortsch M, Isom LL. Structural requirements for interaction of sodium channel $\beta 1$ subunits with ankyrin. J Biol Chem 2002;277:26681-26688. [PubMed: 11997395]

28. McCormick KA, Isom LL, Ragsdale D, Smith D, Scheuer T, Catterall WA. Molecular determinants of $\mathrm{Na}^{+}$channel function in the extracellular domain of the $\beta 1$ subunit. J. Biol. Chem 1998;273:39543962. [PubMed: 9461582]

29. McEwen DP, Isom LL. Heterophilic interactions of sodium channel beta 1 subunits with axonal and glial cell adhesion molecules. J Biol Chem 2004;279:52744-52752. [PubMed: 15466474]

30. McEwen DP, Meadows LS, Chen C, Thyagarajan V, Isom LL. Sodium channel $\beta 1$ subunit-mediated modulation of Nav1.2 currents and cell surface density is dependent on interactions with contactin and ankyrin. J Biol Chem 2004;279:16044-16049. [PubMed: 14761957]

31. Meadows LS, Isom LL. Sodium channels as macromolecular complexes: Implications for inherited arrhythmia syndromes. Cardiovasc Res 2005;67:448-458. [PubMed: 15919069]

32. Morgan K, Stevens EB, Shah B, Cox PJ, Dixon AK, Lee K, Pinnock RD, Hughes J, Richardson PJ, Mizuguchi K, Jackson AP. $\beta 3$ : An additional auxiliary subunit of the voltage-sensitive sodium channel that modulates channel gating with distinct kinetics. Proc. Natl. Acad. Sci. U.S.A 2000;97:2308-2313. [PubMed: 10688874]

33. O'Malley HA, Shreiner AB, Chen GH, Huffnagle GB, Isom LL. Loss of Na+ channel beta2 subunits is neuroprotective in a mouse model of multiple sclerosis. Mol Cell Neurosci 2009;40:143-155. [PubMed: 19013247]

34. Ratcliffe CF, Westenbroek RE, Curtis R, Catterall WA. Sodium channel beta1 and beta3 subunits associate with neurofascin through their extracellular immunoglobulin-like domain. J. Cell Biol 2001;154:427-434. [PubMed: 11470829]

35. Shah BS, Stevens EB, Pinnock RD, Dixon AK, Lee K. Developmental expression of the novel voltagegated sodium channel auxiliary subunit beta3, in rat CNS. J Physiol 2001;534:763-776. [PubMed: 11483707]

36. Shapiro L, Doyle JP, Hansley P, Colman DR, Hendrikson WA. Crystal structure of the extracellular domain from $\mathrm{P}_{\mathrm{O}}$, the major structural protein of peripheral nerve myelin. Neuron 1996;17:435-449. [PubMed: 8816707]

37. Srinivasan J, Schachner M, Catterall WA. Interaction of voltage-gated sodium channels with the extracellular matrix molecules tenascin-C and tenascin-R. Proc. Natl. Acad. Sci. U. S. A 1998;95:15753-15757. [PubMed: 9861042]

38. Vaughn DE, Bjorkman PJ. The (Greek) Key to Structures of Neural Adhesion Molecules. Neuron 1996;16:261-273. [PubMed: 8789942] 
39. Warner LE, Hilz MJ, Appel SH, Killian JM, Kolodny EH, Karpati G, Carpenter S, et al. Clincal Phenotypes of different MPZ $\left(\mathrm{P}_{\mathrm{o}}\right)$ mutations may include Charcot-Marie-tooth-type 1B, DejerineSottas, and congenital hypomyelination. Neuron 1996;17:451-460. [PubMed: 8816708]

40. Williams AF, Barclay AN. The immunoglobulin superfamily--domains for cell surface recognition. Annu Rev Immunol 1988;6:381-405. [PubMed: 3289571]

41. Xiao Z-C, Ragsdale DS, Malhorta JD, Mattei LN, Braun PE, Schachner M, Isom LL. Tenascin-R is a functional modulator of sodium channel $\beta$ subunits. J. Biol. Chem 1999;274:26511-26517. [PubMed: 10473612]

\section{Acknowledgments}

This work was supported by NIH R01MH59980 to LLI. DPM was supported by University of Michigan NIH training grant GM07767 and by an individual NRSA predoctoral fellowship NS43067. 

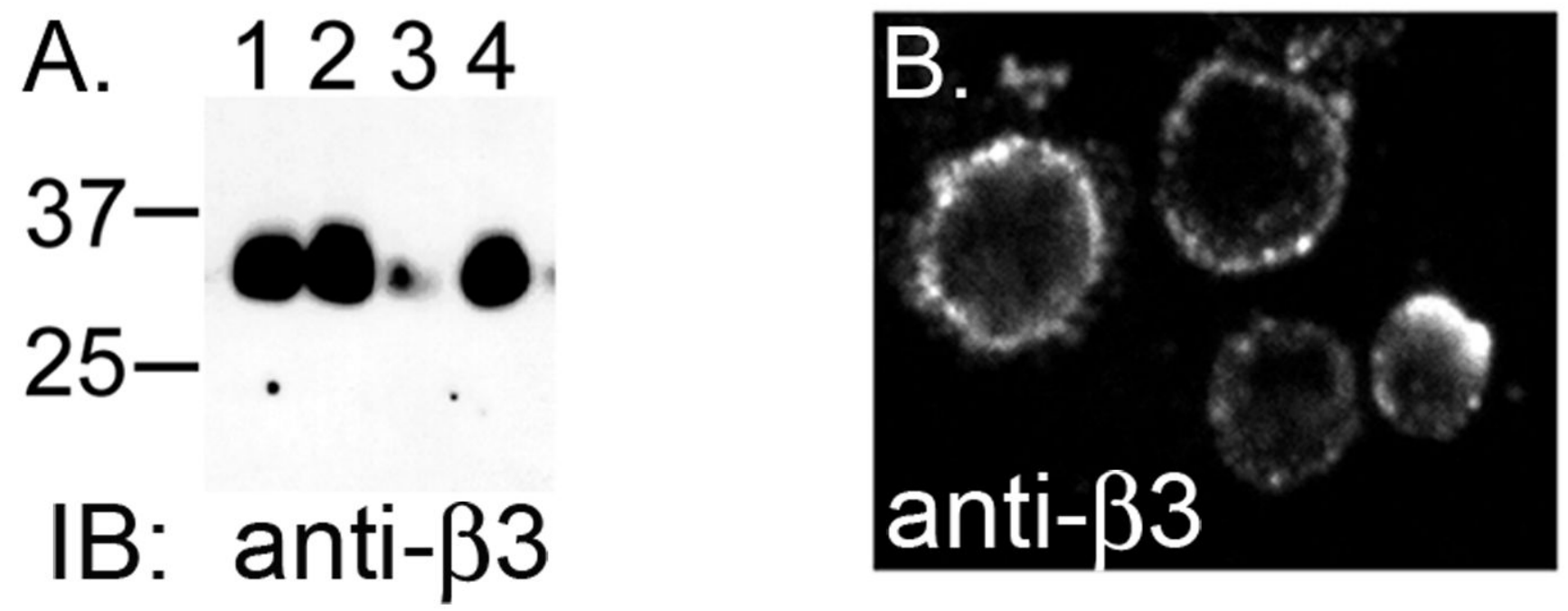

Fig. 1. $\beta 3$ lacks trans homophilic cell adhesive properties

(A), Western blot analysis of Drosophila Schneider's line 2 (S2) cells transfected with $\beta 3$, followed by soft agar cloning to select for stable clones. Protein expression was induced with $0.7 \mathrm{mM} \mathrm{CuSO}_{4}$ for at least $24 \mathrm{~h}$. Immunoblots (IB) were probed with anti- $\beta 3$ antibody (1:500). Four representative clones are shown, three expressing high levels of $\beta 3$ (lanes 1, 2, and 4). (B), Immunocytochemical analysis of $\beta 3$ expression in S2 cells. Cells were fixed and stained with anti- $\beta 3$ antibody (1:50), showing that $\beta 3$ is expressed at the cell surface. None of the S2 33 cell clones aggregated following induction of protein expression and mechanical shaking. Panel shows a representative example of a high-expressing $\beta 3$ cell line. 

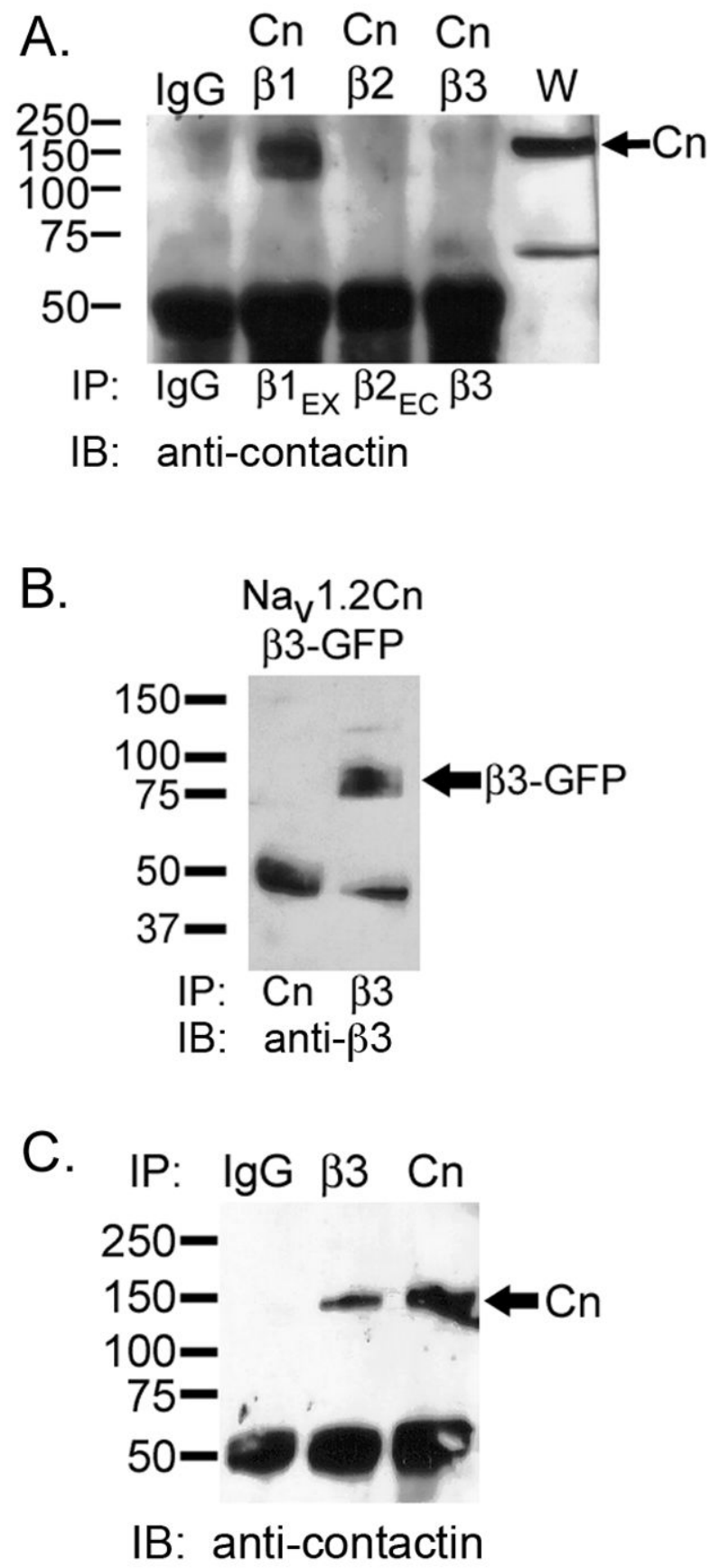

Fig. 2. $\beta 3$ does not associate with contactin

(A), Immunoprecipitation from CHL cells stably expressing contactin and either $\beta 1, \beta 2$, or $\beta 3$, as indicated. Triton X-100 solubilized lysates were immunoprecipitated (IP) with nonimmune $\operatorname{IgG}$, anti- $\beta 1_{\mathrm{EX}}$, anti- $\beta 2_{\mathrm{EC}}$, or anti- $\beta 3$, as indicated, and the immunoblot (IB) was probed with anti-contactin antibody (1:500). $20 \mu \mathrm{g}$ of rat brain lysate were used for positive contactin staining $(\mathrm{W})$. Arrow indicates contactin $(\mathrm{Cn})$ immunoreactive band. The bands at 50 $\mathrm{kDa}$ correspond to the antibody used for immunoprecipitation. (B), Immunoprecipitation from $\mathrm{Na}_{\mathrm{v}} 1.2 / \mathrm{Cn} / \beta 3$-GFP expressing cells. Triton X-100 solubilized lysates were immunoprecipitated (IP) with either anti-contactin antibody (lane 1) or anti- $\beta 3$ antibody (lane 
2 ) and the immunoblot (IB) was probed with anti- $\beta 3$ (1:500). The $\sim 30 \mathrm{kDa}$ increase in the molecular weight of $\beta 3$ (arrow) is due to the presence of the GFP tag. The lower bands at 50 $\mathrm{kDa}$ correspond to the antibodies used for immunoprecipitation. (C), Triton X-100 solubilized rat brain lysates were immunoprecipitated (IP) with nonimmune $\mathrm{IgG}$, anti- $\beta 3$, or anti-contactin antibodies, as indicated. Immunoblotting (IB) with anti-contactin yielded a band at $135 \mathrm{kDa}$ in lanes 2 and 3 (arrow). Equal amounts of lysate were used for each immunoprecipitation. "Cn": contactin. 

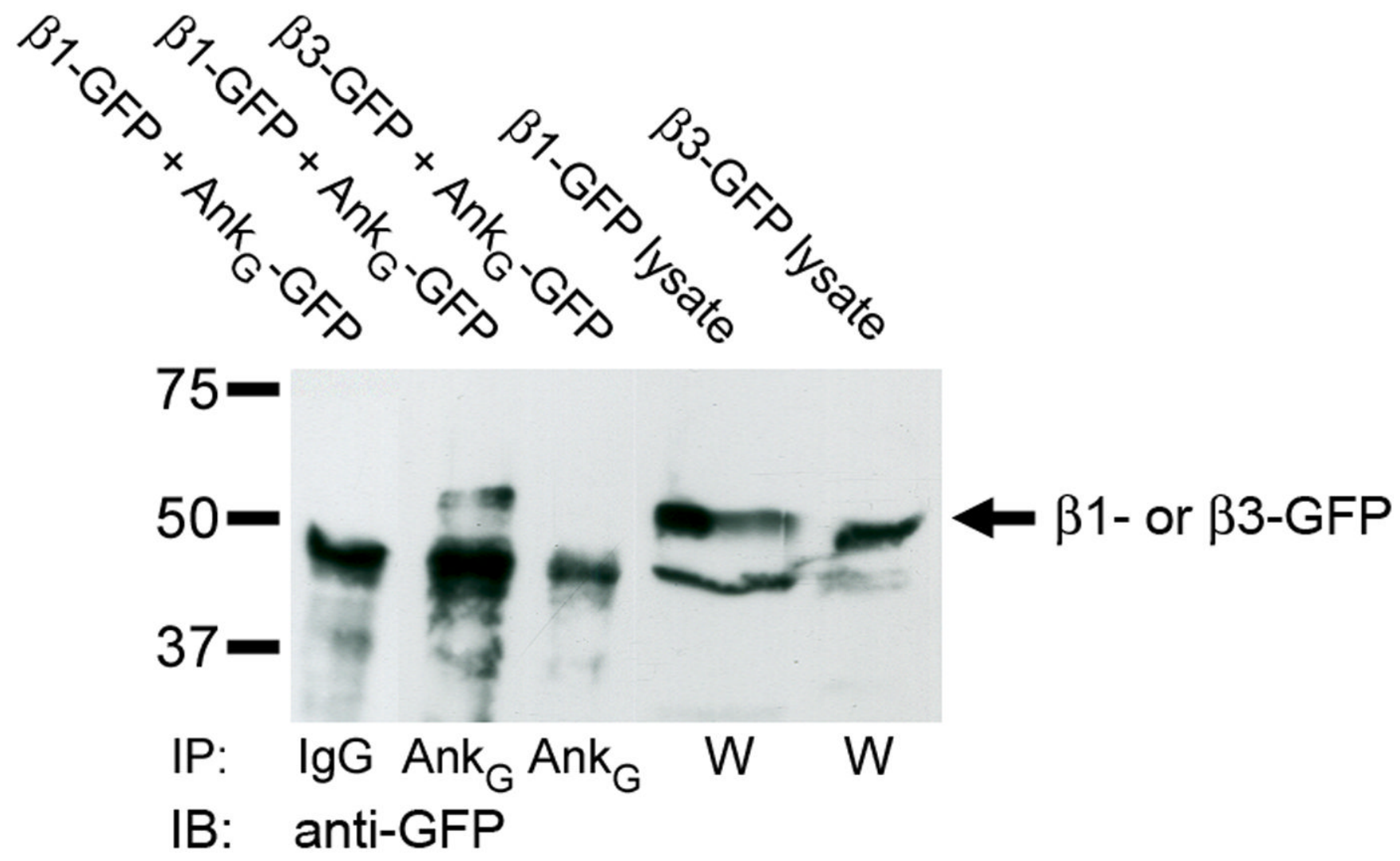

Fig. 3. $\beta 3$ does not interact with ankyrin a $_{\mathrm{G}}$

Immunoprecipitation of $\beta 1-\mathrm{GFP}$ or $\beta 3-\mathrm{GFP}$ with ankyrin $_{\mathrm{G}}-\mathrm{GFP}$ from transiently transfected CHL cells, as indicated. Equal amounts of Triton X-100 solubilized lysates of cells expressing the indicated combinations of $\beta$ subunits and ankyrin $_{\mathrm{G}}$ were immunoprecipitated (IP) with 5 $\mu \mathrm{L}$ of either non-immune $\mathrm{IgG}_{\text {or }}$ anti-ankyrin $_{\mathrm{G}}$, as indicated. Immunoblots (IB) were probed with anti-GFP antibody (1:500). Immunoreactive bands at approximately $60 \mathrm{kDa}$ represent $\beta 1-$ GFP or $\beta 3$-GFP, respectively (arrow). The increase in molecular weight of the $\beta$ subunit immunoreactive bands is due to the addition of the GFP tag. 


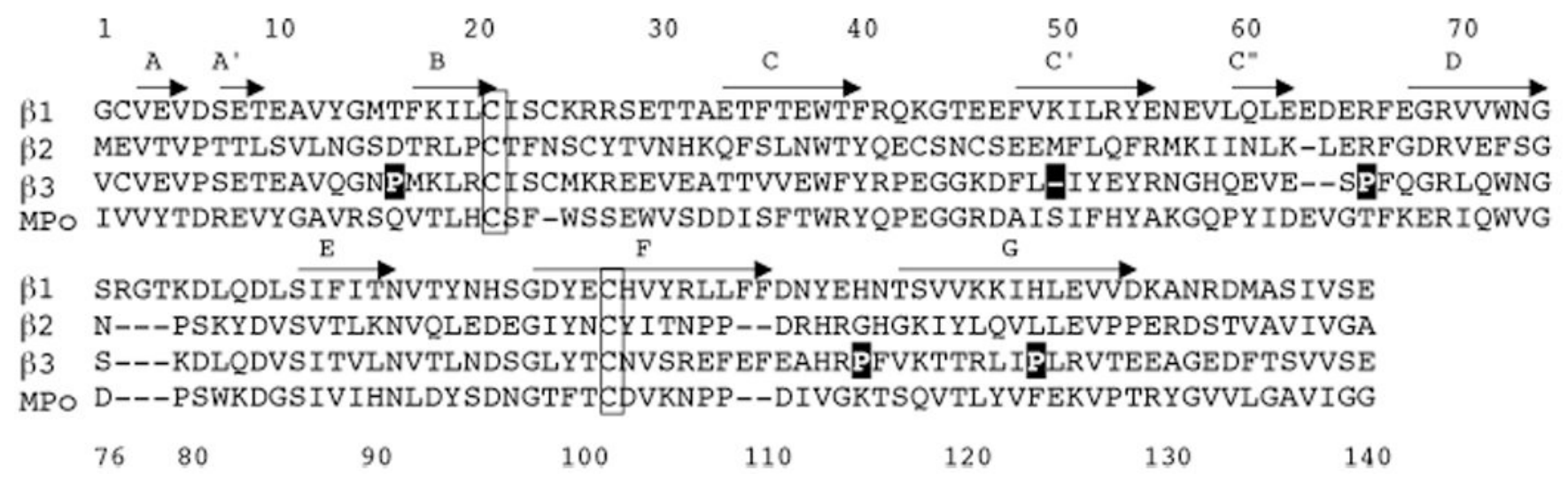

Fig. 4. Sequence alignment of the extracellular domains of $\beta 1, \beta 2, \beta 3$, and $\mathrm{MP}_{0}$

Amino acid sequences for the $\beta 1, \beta 2, \beta 3$, and $\mathrm{MP}_{0}$ extracellular domains were acquired from NCBI ( $\beta 1$ accession number: M91808; $\beta 2$ : NM_012877; $\beta 3$ : AF378093; MP $_{0}$ : NM_017027) and aligned using the program MSA (http://xylian.igh.cnrs.fr/msa/msa.html). Numbering corresponds to the $\beta 1$ amino acid sequence. Arrows indicate positions of $\beta$ sheets in the Ig domain, as in [13]. $\beta 1$ and $\beta 3$ share $\sim 43 \%$ sequence identity. Cysteines involved in formation of the Ig loop are shown in clear boxes. Proline residues unique to $\beta 3$ are highlighted in black. 